\title{
'BMX Ativa' soybean responses after application of biofertilizer associated or not with glyphosate
}

\author{
Leandro Galon $^{1 *} \oplus$, Fernando José Babinski ${ }^{1} \oplus$, César Tiago Forte ${ }^{2}$, Luciane Renata Agazzi ${ }^{1} \oplus$, \\ Alessandra Gallina ${ }^{1} \mathbb{0}$, Gismael Francisco Perin ${ }^{1}[0$
1 Universidade Federal da Fronteira Sul, Campus Erechim, Erechim, RS, Brasil. E-mail: leandro.galone@gmail.com; fernandobabinski01@gmail.com; luci_agazzi@hotmail.com; alessandragallina@hotmail.com; gismaelperin@gmail.com
${ }^{2}$ Syngenta Crop, Erechim, RS, Brasil. E-mail: cesartiagoforte@hotmail.com

ABSTRACT: Even with the development of glyphosate-resistant soybean, there are cases in which harmful effects of intoxication occur, especially when the herbicide is applied in mixture with other products. The objective of this work was to verify the efficiency of biofertilizer as a glyphosate stress reducer in the soybean "BMX Ativa". The experiment was installed in a randomized block design, in a $3 \times 5+1$ factorial scheme, with four replications. In factor A, soybean development stages (V4, V8 and V4 + V8) were allocated, and in factor B the application of $0.1 \mathrm{~L} \mathrm{ha}^{-1}$ of biofertilizer, 1,080 and 2,160 $\mathrm{g} \mathrm{ha}^{-1}$ of a.e. of glyphosate, applied in isolated mode and/or mix in tank, plus one control without application as an additional treatment. The evaluated variables were phytointoxication, number of grains per plant, number of pods per plant, thousand grains mass and soybean grain yield. The application of double the dose of glyphosate $\left(2,160 \mathrm{~g} \mathrm{ha}^{-1}\right)$ alone or in mixture with the biofertilizer in stages V4, V8 and V4 + V8 caused visual injuries to soybean 'BMX Ativa' until 28 days after application, but without affect the productive characteristics of the crop. The biofertilizer did not affect soybean plants and neither mitigate the negative effect of the highest dose of glyphosate.

\section{Respostas de soja 'BMX Ativa' após aplicação de biofertilizante associado ou não ao glyphosate}

RESUMO: Mesmo com o desenvolvimento da soja resistente ao glyphosate há casos em que ocorrem efeitos prejudiciais de intoxicação, principalmente quando o herbicida é aplicado em mistura com outros produtos. Objetivou-se com esse trabalho verificar a eficiência de biofertilizante como redutor de estresse de glyphosate na soja 'BMX Ativa'. O experimento foi instalado em delineamento de blocos casualizados, no esquema fatorial $3 \times 5+1$, com quatro repetições. No fator $A$ alocou-se os estádios de desenvolvimento da soja (V4, V8 e V4 + V8) e no B a aplicação de $0,1 \mathrm{~L} \mathrm{ha}^{-1}$ de biofertilizante, 1.080 e $2.160 \mathrm{~g} \mathrm{ha}{ }^{-1}$ de e. a. de glyphosate, aplicados de modo isolado e/ou em mistura em tanque, mais uma testemunha sem aplicação como tratamento adicional. As variáveis avaliadas foram fitointoxicação, número de grãos por planta, número de vagens por planta, massa de mil grãos e a produtividade de grãos da soja. A dose de $1.080 \mathrm{~g} \mathrm{ha}^{-1}$ de glyphosate apresentou baixa fitotoxicidade. A aplicação do dobro da dose de glyphosate (2.160 $\left.\mathrm{g} \mathrm{ha}^{-1}\right)$ isolado ou em mistura com o biofertilizante nos estádios V4, V8 e V4+V8 ocasionou injúrias visuais à soja 'BMX Ativa' até os 28 dias após a aplicação, mas sem afetar as características produtivas da cultura. 0 biofertilizante (ácido L-glutâmico) não afetou as plantas de soja e nem atenuou o efeito negativo da maior dose de glyphosate.

Palavras-chave: atenuante; bioestimulante; Glycine max (L.) Merrill; injúrias de herbicidas

\footnotetext{
* Leandro Galon - E-mail: leandro.galone@gmail.com (Corresponding author)

Associate Editor: Leandro Pereira Pacheco
} 


\section{Introduction}

The climate in Brazil varies from tropical to subtropical and, for this reason, there is a wide proliferation of insects and diseases, in addition to being favorable to the infestation of many weed species in soybean crop. The control method more utilized is the chemical, using herbicides and, among them, glyphosate, especially for transgenic soybean resistant to this product.

Glyphosate inhibits the action of the enzyme 5-enolpyruvylshikimate 3-phosphate synthase (EPSPs), essential in the biosynthesis of aromatic amino acids, phenylalanine, tyrosine, tryptophan (Melo et al., 2019). This herbicide has a systemic action and its application is in postemergence to control monocotyledons and dicotyledons, both in desiccations and in cleaning crops resistant to it, as RR soybean (Barroso et al., 2014).

Even when the application of glyphosate occurs in resistant soybean cultivars, some injury symptoms can happen after the application of the herbicide, such as the decrease in chlorophyll indexes (Cesco et al., 2018). This is possibly due to the accumulation of AMPA (aminomethylphosphonic), which is characterized as a phytotoxic metabolite that is formed in the degradation of glyphosate (Sharma et al., 2012; Merotto Jr. et al., 2015). Factors such as the physical and chemical characteristics of the herbicides, applied doses, climate and soil conditions and soybean cultivar sown in the crop, can cause variation in the intoxication by the use of products in the crop.

In glyphosate-resisant soybean, yellowing of the leaves may occur after the application of the herbicide, generating a symptom called yellow flashing, which is the visual effect of yellowing in the upper leaves (Zobiole et al., 2010; Merotto Jr. et al., 2015). This occurs due to the immobilization of Fe and $\mathrm{Mn}$ by the herbicide, in which the time and the degree of yellowing depend on the plant's ability to restore the levels of these elements (Merotto Jr. et al., 2015).

Therefore, there are studies, aiming the reduction of the phytotoxic effects, using some products such as foliar fertilizers or biofertilizers in association with the herbicide (Du Jardin, 2015; Andrade et al., 2018; Andrade et al., 2020). These biofertilizers or biostimulants have varied compositions, usually containing amino acids such as L. glutamic acid, which can indirectly reduce oxidative stress effects, as they are a precursor to other amino acids, such as arginine and proline (Du Jardin, 2015; Andrade et al., 2018). These amino acids are correlate with the reduction of stress in the plant, with proline being an amino acid also used in the biosynthetic precursor rout of the chlorophyll molecule (Sharma et al., 2012; Povero et al., 2016).

Another compound of biofertilizers is glycine betaine, which is a solute that acts as an osmoprotector in plants, especially in salt stresses (Sharma et al., 2012; Du Jardin, 2015; Povero et al., 2016). Certain biofertilizers have seaweed extracts in their composition that, depending on the concentration, can explain the effects of the stress recovery on plants and improve production aspects due to the presence of hormones and nutrients that can be used by the crop. Some commercial seaweed have high hormonal levels such as cytokinin or betaines, which act in the retention of chlorophyll and, in the case of betaines, involved in resistance to drought (Marques et al., 2014; Du Jardin, 2015; Andrade et al., 2020).

The present study had as hyphothesis that the use of glyphosate doses associated with biofertlizant reduces the occurrence of injuries in soybean and, consequently, the crop can express the maximum grain yield. The objective of this work was to verify the efficiency of biofertilizer as a glyphosate stress reducer in 'BMX Ativa' soybean.

\section{Materials and Methods}

The experiment was conducted in the field, in the city of Quatro Irmãos/RS from November 2014 to March 2015, with the soil classified as cambisolic Eutrophic Ta Haplic (Embrapa, 2013). The field under study had consolidated no-tillage with more than 10 years of implementation. In Table 1 , it is possible to observe the chemical attributes of the soil in which the experiment was installed.

The soybean sowing was carried out in a no-tillage system, and 20 days before this operation, the area was desiccated with the herbicide glyphosate with a dose of $1,080 \mathrm{~g} \mathrm{ha}^{-1}$ of acid equivalent. The correction of soil fertility was done according to the interpretation of the chemical analysis (Table 1 ), with black oats as the predecessor crop; thus, $350 \mathrm{~kg} \mathrm{ha}^{-1}$ of fertilizer was applied in formulation 02-30-15 N-P-K, resulting in $7 \mathrm{~kg} \mathrm{ha}^{-1}$ of $\mathrm{N}, 105 \mathrm{~kg} \mathrm{ha}^{-1} \mathrm{P}_{2} \mathrm{O}_{5}$ and $52.5 \mathrm{~kg} \mathrm{ha}^{-1}$ of $\mathrm{K}_{2} \mathrm{O}$.

Each experimental unit was composed by a total area of $14.1 \mathrm{~m}^{2}(2.82 \times 5 \mathrm{~m})$ and a useful area of $7.52 \mathrm{~m}^{2}(4 \times 1.88$ $\mathrm{m})$, where sowing of the soybean cultivar 'BMX Ativa' was carried out, with spacing between the six lines of $0.47 \mathrm{~m}$, with $5 \mathrm{~m}$ in length $\left(14.1 \mathrm{~m}^{2}\right)$ and density of 30 plants $\mathrm{m}^{-2}$ and 14.1 seeds meter $^{-1}$, which generated a population of approximately 300,000 plants $\mathrm{ha}^{-1}$. To evaluate the variables of the experiment, the four central lines of the plots were used, leaving one line on each side (left and right, as borders) and $0.5 \mathrm{~m}$ as front borders.

Table 1. Chemical attributes of the soil used to implement the experiment. Quatro Irmãos, RS, Brazil, $2014 / 15$ crop year.

\begin{tabular}{|c|c|c|c|c|c|c|c|c|c|c|c|c|}
\hline \multirow{2}{*}{$\begin{array}{l}\text { SBv } \\
(\%) \\
\end{array}$} & \multirow{2}{*}{$\begin{array}{c}\text { CTC } \\
\left(\mathrm{cmol}_{\mathrm{c}} \mathrm{dm}^{-3}\right) \\
\end{array}$} & \multirow{2}{*}{$\begin{array}{l}\mathrm{pH}^{(1)} \\
\left(\mathrm{H}_{2} \mathrm{O}\right) \\
\end{array}$} & $P$ & $\bar{K}$ & $\mathrm{Ca}^{2+}$ & $\mathrm{Mg}^{2+}$ & $S$ & $\overline{Z n}$ & $\mathrm{Mn}$ & $\mathrm{Cu}$ & B & \multirow{2}{*}{$\begin{array}{l}\text { MO } \\
(\%) \\
\end{array}$} \\
\hline & & & \multicolumn{2}{|c|}{$\left(\mathrm{mg} \mathrm{dm}^{-3}\right)$} & \multicolumn{2}{|c|}{$\left(\mathrm{cmol}_{\mathrm{c}} \mathrm{dm}^{-3}\right)$} & \multicolumn{5}{|c|}{$\left(\mathrm{mg} \mathrm{dm}^{-3}\right)$} & \\
\hline 75.6 & 12.1 & 6.1 & $8^{x}$ & $37^{x}$ & $7.4^{*}$ & $4.0^{*}$ & $6^{x}$ & $2.8^{*}$ & $15^{*}$ & $4.4^{*}$ & $0.4^{*}$ & $2.8^{* *}$ \\
\hline
\end{tabular}

Analysis performed in the 0 to $10 \mathrm{~cm}$ layer. Clay content of $28 \%$. $^{(1)}$ Ideal $\mathrm{pH}$ for soybean cultivation, clay class $3,{ }^{*}$ low levels, ${ }^{*}$ High levels in the soil for soybean cultivation, $* *$ Average content of organic matter, interpretations according to Rolas (2016). 
The experiment was installed in a randomized block design, containing 16 treatments, each one with four replications, in a $3 \times 5+1$ factorial arrangement. Three stages of development $(\mathrm{V} 4, \mathrm{~V} 8, \mathrm{~V} 4+\mathrm{V} 8)$ was combined with five doses of glyphosate and biofertilizer (two glyphosate doses isolated and with addition of biofertilizer and, isolated biofertilizer), plus the weeded control, as described in Table 2.

The products application was done using a precision backpack sprayer, pressurized by $\mathrm{CO}_{2}$, equipped with four fan nozzles model DG 110.02, under constant pressure of $2.0 \mathrm{kgf}$ $\mathrm{cm}^{-2}$ and displacement speed of $3.6 \mathrm{~km} \mathrm{~h}^{-1}$, which provided a flow of $130 \mathrm{~L} \mathrm{ha}^{-1}$ of herbicide and / or biofertilizer solution.

The climatic conditions were verified by the use of a hermo-hygro-anemometer, at the time of the applications, as described in Table 3.

Crop management was carried out according to the technical indications for soybean crop, in which was realized the manual control of weeds that might compromise the results of the research. The management of pests and diseases was carried out when necessary, with four applications of insecticide and fungicide, which were realized in the vegetative and reproductive stages for the crop express the maximum grain yield. During the conduction of the experiment, there was no considerable water deficit (Figure 1).

The intoxication of the products for soybean crop was evaluated visually at 7, 14, 21 and 28 days after the application of the treatments (DAT) and, in the case of V4 + V8, the evaluation occurred after the second application. To evaluate the intoxication of the treatments, percentage visual

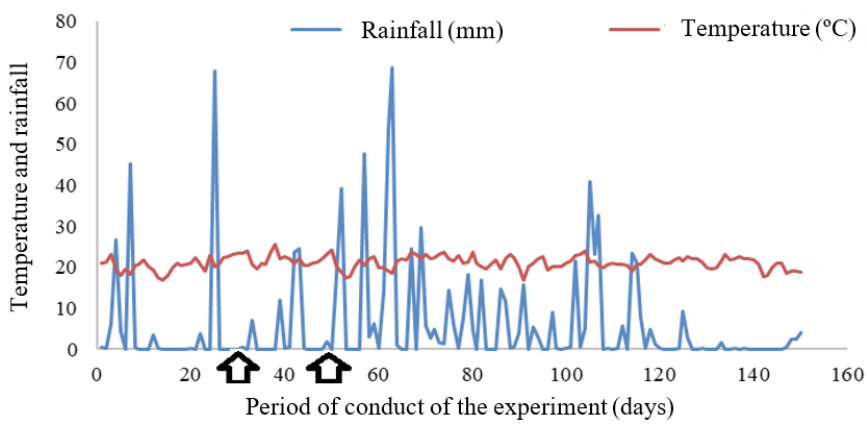

Font: INMET (2020).

Figure 1. Temperature and rainfall during the conduction of the experiment, arrows indicate application at 32 (V4) and 50 (V8) days after sowing. Quatro Irmãos, RS, Brazil, 2014/15 crop year.

scores were attributed, in which zero (0\%) corresponded to the absence of injuries in soybean and the hundred note $(100 \%)$ to the death of plants, according to the methodology proposed by SBCPD (1995).

In the pre-harvest, 10 plants were randomly collected in each experimental unit to determine the number of grains plant $^{-1}$ and the number of pods plant ${ }^{-1}$. The harvest was carried out when the grains reached $15 \%$ humidity, in a useful area of $2.82 \mathrm{~m}^{2}$ per experimental unit, and threshing was subsequently carried out with a plot thresher. After the harvest, the mass of one thousand grains (g) was determined counting 8 samples of 100 grains, with a subsequent proportion to one thousand, weighing them in an analytical balance. For the analysis, the

Table 2. Treatments with its respective doses of biofertilizer, glyphosate and application stages in soybean 'BMX Ativa'. Quatro Irmãos, RS, Brazil, 2014/15 crop year.

\begin{tabular}{|c|c|c|c|c|}
\hline Treatments & $\begin{array}{c}\text { Dose of biofertilizer } \\
\left(\mathrm{L} \mathrm{ha}^{-1}\right)\end{array}$ & $\begin{array}{c}\text { Dose of glyphosate } \\
\text { (g a. e. ha-1) }\end{array}$ & $\begin{array}{c}\text { Stage } \\
\text { of application } \\
\end{array}$ & $\begin{array}{c}\text { Mode } \\
\text { of application }\end{array}$ \\
\hline Weeded control & $\ldots$ & $\ldots$ & $\ldots$ & $\ldots$ \\
\hline Glyphosate** & $\ldots$ & 1,080 & V4 & Single \\
\hline Glyphosate** $^{* *}$ & $\ldots$ & 2,160 & V4 & Single \\
\hline Glyphosate** + L-glutamic acid* & 0.1 & 1,080 & V4 & Single \\
\hline Glyphosate $^{* *}+$ L-glutamic acid * & 0.1 & 2,160 & V4 & Single \\
\hline Weeding + L-glutamic acid * & 0.1 & $\ldots$ & V4 & Single \\
\hline Glyphosate** & $\ldots$ & 1,080 & V8 & Single \\
\hline Glyphosate** & $\ldots$ & 2,160 & V8 & Single \\
\hline Glyphosate** + L-glutamic acid* $^{*}$ & 0.1 & 1,080 & V8 & Single \\
\hline Glyphosate** + L-glutamic acid* $^{*}$ & 0.1 & 2,160 & V8 & Single \\
\hline Weeding + L-glutamic acid * & 0.1 & $\ldots$ & V8 & Single \\
\hline Glyphosate** & $\ldots$ & $(1,080+1,080)$ & $\mathrm{V} 4+\mathrm{V} 8$ & Sequential \\
\hline Glyphosate** $^{* *}$ & $\ldots$ & $(2,160+2,160)$ & $V 4+V 8$ & Sequential \\
\hline Glyphosate** + L-glutamic acid* $^{*}$ & $(0.1+0.1)$ & $(1,080+1,080)$ & $V 4+V 8$ & Sequential \\
\hline Glyphosate $^{* *}+$ L-glutamic acid* & $(0.1+0.1)$ & $(2,160+2,160)$ & $V 4+V 8$ & Sequential \\
\hline Weeding + L-glutamic acid* & $(0.1+0.1)$ & $\ldots$ & $\mathrm{V} 4+\mathrm{V} 8$ & Sequential \\
\hline
\end{tabular}

${ }^{*}$ Vorax and $^{* *}$ Roundup Original ${ }^{\circ}$

Table 3. Environmental conditions in the time of the application of the treatments at different stages of delopment of soybean cultivar 'BMX Ativa'. Quatro Irmãos, RS, Brazil, 2014/15 crop year.

\begin{tabular}{|c|c|c|c|c|c|c|}
\hline \multirow{2}{*}{$\begin{array}{c}\text { Soybean } \\
\text { stage }\end{array}$} & \multirow{2}{*}{$\begin{array}{c}\text { Luminosity } \\
(\%)\end{array}$} & Air temperature & Soil temperature & \multirow{2}{*}{$\begin{array}{c}\text { Relatve } \\
\text { humidity (\%) }\end{array}$} & \multirow{2}{*}{$\begin{array}{c}\text { Soil } \\
\text { conditions }\end{array}$} & \multirow{2}{*}{$\begin{array}{c}\text { Wind speed } \\
\left(\mathrm{km} \mathrm{h}^{-1}\right)\end{array}$} \\
\hline & & \multicolumn{2}{|c|}{$\left({ }^{\circ} \mathrm{C}\right)$} & & & \\
\hline V4 & 100 & 28.0 & 27.1 & 50 & humid & 5 to 8 \\
\hline V8 & 70 & 28.9 & 24.7 & 71 & humid & 1 to 3 \\
\hline
\end{tabular}


grain humidity was adjusted to $13 \%$ and the grain yield data extrapolated to $\mathrm{kg} \mathrm{ha}^{-1}$.

The data were subjected to analysis of variance by the $F$ test and, when significant $(p<0.05)$ they were subjected to comparison of means by the Tukey's test.

\section{Results and Discussion}

The results of the variance analysis demonstrate that occured a significant effect ( $p \leq 0.05$ ) for intoxication at 7,14 , 21 and 28 days after the application of treatments (DAT). The number of pods per plant, number of grains per plant, mass of one thousand grains and grain yield did not show a significant effect ( $p \geq 0.05$ ).

It was observed a high intoxication in the soybean at 7 DAT when applied the highest dose of glyphosate, isolated or associated with the biofertilizer, in stages V4, V8 and V4 + V8 (Table 4). The other treatments showed low intoxications, with rates below $9 \%$. The highest dose of glyphosate caused intoxication that reached $17 \%$, probably overloading the way by which soybean degrades the herbicide through the AMPA - aminomethylphosphonic route (Franco et al., 2012; Andrade et al., 2020). Intoxication is more perceptible close

Table 4. Intoxication (\%) of 'BMX Ativa' soybean due to the application of glyphosate doses, development stages and association or not with the biofertilizer, evaluated at 7, 14, 21 and 28 days after application.

\begin{tabular}{|c|c|c|c|}
\hline Treatments & Stage V4 & StageV8 & Stages V4 + V8 \\
\hline & \multicolumn{3}{|c|}{ Intoxication 7 DAT (\%) } \\
\hline Control without application & $0 \mathrm{eA}^{1}$ & $0 \mathrm{cA}$ & $0 \mathrm{dA}$ \\
\hline Glyphosate $1,080 \mathrm{~g} \mathrm{ha}^{-1}$ & $6 \mathrm{cA}$ & $4 \mathrm{bA}$ & $4 \mathrm{cA}$ \\
\hline Glyphosate $2,160 \mathrm{~g} \mathrm{ha}^{-1}$ & $10 \mathrm{bB}$ & $9 \mathrm{aB}$ & $16 \mathrm{aA}$ \\
\hline Glyphosate $1,080 \mathrm{~g} \mathrm{ha}^{-1}+$ biofertilizer & $5 \mathrm{cdB}$ & $3 \mathrm{bcB}$ & $8 \mathrm{bA}$ \\
\hline Glyphosate $2,160 \mathrm{~g} \mathrm{ha}^{-1}+$ biofertilizer & 17 aA & $\mathrm{OcC}$ & $14 \mathrm{aB}$ \\
\hline Biofertilizer & $1 \mathrm{de} A$ & $0 \mathrm{cA}$ & $2 \mathrm{cdA}$ \\
\hline \multirow[t]{2}{*}{ C.V. (\%) } & \multicolumn{3}{|c|}{20.80} \\
\hline & \multicolumn{3}{|c|}{ Intoxication 14 DAT (\%) } \\
\hline Control without application & $0 \mathrm{dA}$ & $0 \mathrm{bA}$ & $0 \mathrm{CA}$ \\
\hline Glyphosate $1,080 \mathrm{~g} \mathrm{ha}^{-1}$ & $3 \mathrm{cA}$ & $1 \mathrm{abB}$ & 2 bcAB \\
\hline Glyphosate $2,160 \mathrm{~g} \mathrm{ha}^{-1}$ & $5 \mathrm{bA}$ & $3 a \mathrm{a}$ & $3 a b B$ \\
\hline Glyphosate $1,080 \mathrm{~g} \mathrm{ha}^{-1}+$ biofertilizer & $3 \mathrm{cA}$ & $1 \mathrm{bB}$ & $2 \mathrm{bcB}$ \\
\hline Glyphosate $2,160 \mathrm{~g} \mathrm{ha}^{-1}+$ biofertilizer & 9 aA & $3 \mathrm{aB}$ & $4 \mathrm{aB}$ \\
\hline Biofertilizer & $0 \mathrm{dA}$ & $2 \mathrm{abA}$ & $0 \mathrm{cA}$ \\
\hline \multirow[t]{2}{*}{ C.V. $(\%)$} & & 35.99 & \\
\hline & \multicolumn{3}{|c|}{ Intoxication 21 DAT (\%) } \\
\hline Control without application & $0 \mathrm{cA}$ & $0 \mathrm{bA}$ & $0 \mathrm{cA}$ \\
\hline Glyphosate $1,080 \mathrm{~g} \mathrm{ha}^{-1}$ & $1 \mathrm{bcAB}$ & $0 \mathrm{bB}$ & $1 \mathrm{bcA}$ \\
\hline Glyphosate $2,160 \mathrm{~g} \mathrm{ha}^{-1}$ & $2 \mathrm{bB}$ & $2 \mathrm{aB}$ & $4 \mathrm{aA}$ \\
\hline Glyphosate $1,080 \mathrm{~g} \mathrm{ha}^{-1}+$ biofertilizer & $1 \mathrm{bcA}$ & $\mathrm{ObB}$ & $1 \mathrm{bA}$ \\
\hline Glyphosate $2,160 \mathrm{~g} \mathrm{ha}^{-1}+$ biofertilizer & 5 aA & $\mathrm{ObB}$ & $4 \mathrm{aA}$ \\
\hline Biofertilizer & $0 \mathrm{cA}$ & $0 \mathrm{bA}$ & $0 \mathrm{cA}$ \\
\hline \multirow[t]{2}{*}{ C.V. (\%) } & & 51.47 & \\
\hline & \multicolumn{3}{|c|}{ Intoxication 28 DAT (\%) } \\
\hline Control without application & $0 \mathrm{cA}$ & $0 \mathrm{aA}$ & $0 \mathrm{bA}$ \\
\hline Glyphosate $1,080 \mathrm{~g} \mathrm{ha}^{-1}$ & $3 \mathrm{bA}$ & $0 \mathrm{aB}$ & $3 \mathrm{aA}$ \\
\hline Glyphosate $2,160 \mathrm{~g} \mathrm{ha}^{-1}$ & $3 \mathrm{bA}$ & $0 \mathrm{aB}$ & 3 aA \\
\hline Glyphosate $1,080 \mathrm{~g} \mathrm{ha}^{-1}+$ biofertilizer & $2 \mathrm{bA}$ & $0 \mathrm{aB}$ & $3 \mathrm{aA}$ \\
\hline Glyphosate $2,160 \mathrm{~g} \mathrm{ha}^{-1}+$ biofertilizer & 5 aA & $\mathrm{OaC}$ & $4 \mathrm{aB}$ \\
\hline Biofertilizer & $0 \mathrm{cA}$ & $0 \mathrm{aA}$ & $0 \mathrm{bA}$ \\
\hline C.V. (\%) & \multicolumn{3}{|c|}{50.67} \\
\hline
\end{tabular}

${ }^{1}$ Averages followed by the same lower case letters in the column and upper case in the lines do not differ by the Tukey test at $5 \%$. to the application and tends to reduce over time. Reddy \& Zablotowicz (2003) verified intoxications from 29 to $38 \%$, two days after the application of glyphosate isopropylamine salt and trimethylsulfonium salt in V4, but even so it did not cause productivity losses in soybean. Reis et al. (2010) observed intoxication of $55.5 \%$ in the soybean cultivar M-SOY 8925 RR using the formulation Roundup Transorb ${ }^{\circledR}$, dose of 2,000 $\mathrm{g} \mathrm{ha}^{-1}$, at 17 DAT, but glyphosate did not change the shoot dry mass.

Regarding the use of biofertilizer, Pires (2017) found no interaction between the application of glyhosate plus biostimulant in V3 or sequential in V4, only mild intoxication, evaluated at 3, 7 and 15 DAT in NA 5909 RR soybean cultivar using the dose of $1,440 \mathrm{~g} \mathrm{ha}^{-1}$ of glyphosate. Even if it is a "RR" soybean cultivar, physiological damage caused by the application of glyphosate may occur. The effects will vary according to the cultivar, dose and formulation of the herbicide, environmental conditions at the time and after application (Andrade et al., 2018; Andrade et al., 2020). According to Andrade et al. (2018), the biofertilizer is used to minimize these effects, as it promotes plant growth indirectly and assists the growth of meristems in the plant, however, this was not evidenced on the experiment.

Comparing the intoxication between the soybean development stages, in general, the results demonstrate greater injuries when applying the treatments in $\mathrm{V} 4+\mathrm{V} 8$ (Table 4). As it is a sequential application, the dose used in the crop cycle was double that the other treatments. According to Franco et al. (2012), one of the forms resulting from the degradation of glyphosate is AMPA (aminomethylphosphonic), which is less toxic than glyphosate, but even so it causes intoxication in applications with high doses, being another aggravating when applied in sequence, taking more time for the exudation of this compound by soybean roots.

The use of doses of glyphosate above the recommendations in initial stage of the crop and with low leaf area index (IAF) is harmful. It is supposed that the low IAF causes limited capacity to metabolize glyphosate by soybean and this causes injury to the crop. Melhorança Filho et al. (2010) used different doses of glyphosate in the V4 stage and at 7 days after the application of $2400 \mathrm{~g} \mathrm{ha}^{-1}$, they obtained $13 \%$ intoxication to soybean ' $C D-212 R R^{\prime}$, partially corroborating the results obtained in the present study. Alonso et al. (2013) found intoxication rates by glyphosate in soybean close to $30 \%$ at 7 DATs in the development stages V1 to V2 and V3 to V4, in the doses of 720, 960, 1,200 and 1,440 $\mathrm{g} \mathrm{ha}^{-1}$.

In all stages, the control without application (weeded) did not show intoxication when compared to other treatments. This is due to the fact that only insecticide and fungicide applications were carried out, which did not cause visual injuries. Thus, glyphosate and biofertilizer intoxication was only verified when applied alone or in mixtures (Table 4).

The second evaluation of intoxication done at 14 DAT, the dose of $2160 \mathrm{~g} \mathrm{ha}^{-1}$ of glyphosate and $2160 \mathrm{~g} \mathrm{ha}^{-1}$ of glyphosate + biofertilizer caused injuries of 9 and $5 \%$ to soybean plants, respectively, in V4 (Table 4). In the application in V8 and in the sequential V $4+V 8$, the two treatments involving the dose 
of 2,160 $\mathrm{g} \mathrm{ha}^{-1}$ of glyphosate and glyphosate $\left(2,160 \mathrm{~g} \mathrm{ha}^{-1}\right)+$ biofertilizer presented the highest values of intoxication; the other treatments showed intoxication below $3 \%$.

Among soybean growing stages, application in V4 was harmful, followed by V4 + V8 and finally V8 (Table 4). Zobiole et al. (2010) when testing glyphosate at different development stages of RR soybean found that the herbicide applied in V2 was more harmful than in V4 and V6. This effect is probably due to the smaller leaf area of soybean plants and thus occurs less degradation capacity and exudation of the herbicide.

At 21 DAT, the intoxication in V4 by the treatment with $2,160 \mathrm{~g} \mathrm{ha}^{-1}$ glyphosate + biofertilizer was $5 \%$, in other words, the highest (Table 4). In V8 stage, only the use of glyphosate $\left(2,160 \mathrm{~g} \mathrm{ha}^{-1}\right)$ caused injuries to soybean when compared to the other treatments. The use of glyphosate $\left(2,160 \mathrm{~g} \mathrm{ha}^{-1}\right)$ and glyphosate $\left(2,160 \mathrm{~g} \mathrm{ha}^{-1}\right)+$ biofertilizer provided the greatest intoxications. The other treatments caused minor intoxication symptoms or they were equal to the control without application. Reis et al. (2010) applied doses of glyphosate to soybean 'M-SOY $8925 \mathrm{RR}^{\prime}$ at stage V5 and found intoxication using $1000 \mathrm{~g} \mathrm{ha}^{-1}$.

The application of treatments sequentially in V4 + V8 caused greater injuries to soybean when compared to the other periods of application (Table 4). Forte et al. (2019) applied glyphosate (1,080 and 2,160 $\left.\mathrm{g} \mathrm{ha}^{-1}\right)$ to 'BMX Ativa' soybean and they found low intoxication at 14 and 28 days after application of the treatments.

At 28 DAT, low intoxication was observed in soybean, with a maximum of $5 \%$ when applied glyphosate $(2,160$ $\mathrm{g} \mathrm{ha}^{-1}$ ) + biofertilizer in V4 and $4 \%$ when using the same treatment, but in V4 + V8 (Table 4). The other treatments provided lower values or were equal to the control without application. At 28 DAT, in general, the use of glyphosate plus biofertilizer or isolated glyphosate, even in high doses, caused insignificant intoxication, thus showing the plant's ability to recover. According to Bossolani et al. (2018), this is because the isomorphism of the EPSPs enzyme is not altered by the product, occurring a decrease in the physiological activity of the plant after application, which recovers in a few days. Forte et al. (2019), applied 1,080 and 2,160 $\mathrm{g} \mathrm{ha}^{-1}$ of glyphosate to the cultivar 'BMX Ativa' with 3 trifoliate leaves and they did not observe intoxication at 28 DAT, thus confirming the recovery capacity of soybean, a result similar to the present study.

The use of glyphosate $\left(2,160 \mathrm{~g} \mathrm{ha}^{-1}\right)+$ biofertilizer caused the biggest intoxications, mainly in V4, followed by glyphosate $\left(2,160 \mathrm{~g} \mathrm{ha}^{-1}\right)$. Higher than recommended doses of glyphosate cause greater intoxication to the soybean crop, mainly in the initial stages of development and associated with biofertilizer.

In the present study, there was no effect by treatments for the number of pods per plant at any application stage of the products (Table 5). Alonso et al. (2011) also found no effect on the number of pods per plant when using glyphosate alone, in different doses, in stages V2 and V3 of soybean, which is similar to the data in the present study. It is presumed that soybean were able to recover from intoxication symptoms
Table 5. Number of pods per plant ${ }^{-1}$ of the 'BMX Ativa' soybean depending on the application of glyphosate doses, stages of development and association or not with the biofertilizer.

\begin{tabular}{lccc}
\hline \multirow{2}{*}{\multicolumn{1}{c}{ Treatments }} & \multicolumn{3}{c}{ Number of pods plant ${ }^{-1}$} \\
\cline { 2 - 4 } & Stage V4 & Stage V8 & Stages V4 + V8 \\
\hline Control without application & $43^{\text {ns }}$ & $43^{\text {ns }}$ & $43^{\text {ns }}$ \\
Glyphosate 1,080 g ha $^{-1}$ & 42 & 42 & 39 \\
Glyphosate 2,160 g ha $^{-1}$ & 39 & 46 & 38 \\
Glyphosate 1,080 g ha $^{-1}+$ biofertilizer & 42 & 46 & 46 \\
Glyphosate 2,160 g ha-1 + biofertilizer $^{-1}$ & 37 & 42 & 42 \\
Biofertilizer & 44 & 43 & 42 \\
C.V. (\%) & \multicolumn{4}{c}{14.69} \\
\hline
\end{tabular}

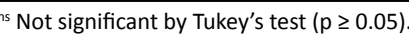

before flowering or the products applied do not cause pod abortion. In a study realized by Melhorança Filho et al. (2010), the number of pods per plant was negatively affected by glyphosate doses above $1,800 \mathrm{~g} \mathrm{ha}^{-1}$, which is above the recommended, thus demonstrating that doses above the recommended, in addition to harming the environment, increase production costs and can also cause damage to the crop. As a opposite result to the present study, Bertolin et al. (2010) found an increase in the number of pods per plant with the use of a biostimulant composed of cytokinin, indolbutyric acid and gibberellic acid (Stimulate) by seed treatment or by foliar application at different phenological stages in two soybean cultivars, in V5, R1 and R5. The authors point out that the phenological stage with the best response was the reproductive one and there was no difference in the application to the seed or leaf.

The variable of number of grains per plant showed no difference between the control treatment and the other combinations of glyphosate doses, crop stages and use of biofertilizer (Table 6).

In the evaluation of the use of glyphosate applied in a mixture with leaf fertilizer in two soybean cultivars, Merotto Jr et al. (2015) found no statistical difference in the number of grains per plant, number of grains per pod and weight of a thousand grains. Thus, the herbicide and the biofertilizer do not alter the yield components, only causes low intoxication in the crop, which had no difference in the presence or not of the biofertilizer.

The results do not demonstrate the occurrence of statistical significance between the tested treatments and neither between application stages, for the mass of one thousand soybean grains (Table 7). Zadinelo et al. (2012) also found no

Table 6. Number of grains per plant ${ }^{-1}$ of 'BMX Ativa' soybean depending on the application of glyphosate doses, stages of development and association or not with biofertilizer.

\begin{tabular}{lccc}
\hline \multirow{2}{*}{ Treatments } & \multicolumn{3}{c}{ Number of pods plant ${ }^{-1}$} \\
\cline { 2 - 4 } & Stage V4 & Stage V8 & Stages V4 + V8 \\
\hline Control without application & $95^{\text {ns }}$ & $95^{\text {ns }}$ & $95^{\text {ns }}$ \\
Glyphosate 1,080 g ha $^{-1}$ & 98 & 95 & 87 \\
Glyphosate 2,160 g ha-1 $^{-1}$ & 87 & 94 & 80 \\
Glyphosate 1,080 g ha-1 + biofertilizer $^{-1,89}$ & 89 & 101 & 104 \\
Glyphosate 2,160 g ha-1 + biofertilizer $^{-10}$ & 81 & 98 & 91 \\
Biofertilizer & 96 & 98 & 89 \\
C.V. (\%) & \multicolumn{3}{c}{15.24} \\
\hline
\end{tabular}

${ }^{\text {ns }}$ Not significant by Tukey's test $(p \geq 0.05)$. 
Table 7. Mass of one thousand grains of soybean 'BMX Ativa' according to the application of glyphosate doses, stages of development and association or not with biofertilizer.

\begin{tabular}{lccc}
\hline \multirow{2}{*}{ Treatments } & \multicolumn{3}{c}{ Mass of one thousand grains(g) } \\
\cline { 2 - 4 } & Stage V4 & Stage V8 & Stages V4 + V8 \\
\hline Control without application & $161^{\mathrm{ns}}$ & $161^{\mathrm{ns}}$ & $161^{\mathrm{ns}}$ \\
Glyphosate 1,080 $\mathrm{g} \mathrm{ha}^{-1}$ & 162 & 168 & 165 \\
Glyphosate 2,160 $\mathrm{g} \mathrm{ha}^{-1}$ & 170 & 172 & 167 \\
Glyphosate 1,080 $\mathrm{g} \mathrm{ha}^{-1}+$ biofertilizer & 165 & 163 & 168 \\
Glyphosate 2,160 $\mathrm{g} \mathrm{ha}^{-1}+$ biofertilizer & 169 & 169 & 173 \\
Biofertilizer & 164 & 163 & 163 \\
C.V. (\%) & \multicolumn{4}{c}{6.05} \\
\hline
\end{tabular}

${ }^{n s}$ Not significant by Tukey's test ( $\left.p \geq 0.05\right)$.

difference in the mass of one thousand grains considering the stage of the soybean crop and the application of glyphosate. Thus, it is presumed that the post-emergence application of glyphosate in different vegetative stages does not change the mass of one thousand grains. Pinto et al. (2016) used three glyphosate doses, 540, 1,080 and 2,160 $\mathrm{g} \mathrm{ha}^{-1}$, in the stages V3 and V4, V8 and R7 in without deficiency soil, they also found no difference in the mass of one thousand grains.

Marques et al. (2014), studying the use of biostimulant based on seaweed extract and amino acids from plant origin in different doses in soybean 'NA 5909RG', found no statistical differences for the mass of 1,000 grains, when testing doses from 1 to $1.5 \mathrm{~L} \mathrm{ha}^{-1}$ of biostimulant, being applied at 30, 45 and 60 after soybean emergence.

The grain yield did not differ statistically from the control without application, and there was no difference between glyphosate doses, stages of application and use of biofertilizer (Table 8 ). These results are similar to those found by Pinto et al. (2016), the authors tested glyphosate doses applied at various stages of the crop and also found no statistical difference between the treatments. Andrade et al. (2020) used different glyphosate formulations and did not find differences in grain yield of RR soybean cultivar (TMG 7062 IPRO ${ }^{\circ}$ ). Possibly, this result occurred because a glyphosateresistant cultivar was used, so it has the ability to metabolize the herbicide, recovering from the intoxication effects without harming productivity.

The use of glyphosate formulations at the R1 stage, with different doses and in two harvests, caused differences in results (Albrecht et al., 2014a). In the first harvest, occured a water deficit, causing a reduction in yield as the dose of

Table 8. Productivity of 'BMX Ativa' soybean grains depending on the application of glyphosate doses, stages of development and association or not with biofertilizer.

\begin{tabular}{|c|c|c|c|}
\hline \multirow[t]{2}{*}{ Treatments } & \multicolumn{3}{|c|}{$\begin{array}{c}\text { Productivity of soybean } \\
\text { grains }\left(\mathrm{kg} \mathrm{ha}^{-1}\right)\end{array}$} \\
\hline & Stage V4 & Stage V8 & Stages V4 + V8 \\
\hline Control without application & $4356 \mathrm{~ns}$ & $4356^{\mathrm{ns}}$ & $4356^{\mathrm{ns}}$ \\
\hline Glyphosate $1,080 \mathrm{~g} \mathrm{ha}^{-1}$ & 4249 & 4622 & 4298 \\
\hline Glyphosate $2,160 \mathrm{~g} \mathrm{ha}^{-1}$ & 4174 & 4036 & 4350 \\
\hline Glyphosate $1,080 \mathrm{~g} \mathrm{ha}^{-1}+$ biofertilizer & 4142 & 4384 & 4162 \\
\hline Glyphosate 2,160 $\mathrm{g} \mathrm{ha}^{-1}+$ biofertilizer & 4357 & 4210 & 4057 \\
\hline Biofertilizer & 4170 & 4371 & 4432 \\
\hline C.V. (\%) & \multicolumn{3}{|c|}{8.48} \\
\hline
\end{tabular}

${ }^{\text {ns }}$ Not significant by Tukey's test ( $\left.p \geq 0.05\right)$. glyphosate applied was increased. In the second harvest, without water deficit, there was no reduction in productivity by glyphosate application. This result was similar to what was found in the present study, in which there was no water deficit, and the grain yield did not differ in face of glyphosate doses and application stages. Thus, it can be inferred that the herbicide has an influence according to environmental conditions, among other factors.

Albrecht et al. (2014b) also describe that glyphosate does not alter soybean grain productivity when applied 0,360 , $720,1,080$ and $1,440 \mathrm{~g} \mathrm{ha}^{-1}$ of the herbicide between V4 and V5 stages, not resulting in a statistical difference between treatments.

\section{Conclusions}

The application of double the dose of glyphosate $(2,160 \mathrm{~g}$ $\mathrm{ha}^{-1}$ ) alone or in mixture with the biofertilizer in stages V4, V8 and V4 + V8 caused visual injuries to 'BMX Ativa' soybean until 28 days after application, but without affect the productive characteristics of the crop.

The biofertilizer (L-glutamic acid) did not affect soybean plants and neither attenuated the negative effect of the highest glyphosate dose.

\section{Acknowledgments}

To CNPq and FAPERGS, for the financial support to the research and for the granting of scholarships.

\section{Compliance with Ethical Standards}

Funding: The authors thank the Conselho Nacional de Desenvolvimento Científico e Tecnológico - CNPq (Process number: 406221/2016-2 and 306927/2019-5), to the Fundação de Amparo à Pesquisa do Estado do Rio Grande do Sul-FAPERGS (Process number: 18/2551-0000623-8) and and to the Financiadora de Estudos e Projetos - FINEP (Process number - 0752/13) for financial support and for fellowships the L. Galon, L. R. Agazzi and C. T. Forte.

Conflict of interest: There is no conflict of interest.

Author contribution: Conceptualization: LG, CTF; Data curation: FJB, LRA; Formal analysis: LG, CTF, GFP; Funding acquisition and Supervision: LG; Investigation: LG, CTF, GFP, FJB; Methodology: LG, FJB, LRA; Project administration, Resources and Validation: LG, GFP; Writing - original draft: FJB, AG, CTF; Writing - review \& editing: LG, AG, FJB, CTF.

\section{Literature Cited}

Albrecht, A.J.P.; Albrecht, L.P.; Krenchinski, F.H.; Placido, H.F.; Lorenzetti, J.B.; Victoria Filho, R.; Barroso, A.A.M. Comportamento da soja RR submetida a diferentes formulações e doses de glyphosate no período reprodutivo. Planta Daninha, v.32, n.4, p.851-859, 2014a. https://doi.org/10.1590/S010083582014000400020 . 
Albrecht, L.P.; Albrecht, A.J.P.; Braccini, A.L.; Oliveira Jr., R.S.; Zobiole, L.H.S.; Ávila, M.R. Glyphosate na produção e qualidade das sementes de soja RR. Planta Daninha, v. 32, n. 2, p. 401-407, 2014b. https://doi.org/10.1590/S0100-83582014000200018.

Alonso, D.G.; Constantin, J.; Oliveira Jr., R.S.; Santos, G.; Dan, H.A.; Oliveira Neto, A.M. Seletividade de glyphosate isolado ou em misturas para soja RR em aplicações sequenciais. Planta Daninha, v.31, n.1, p.203-212, 2013. https://doi.org/10.1590/s010083582013000100022.

Alonso, D.G; Constantin, J; Oliveira Jr, R.S; Arantes, J.G.Z; Cavalieri, S.D; Santos, G; Rios, F.A; Franchini, L.H.M. Seletividade de glyphosate em misturas em tanque para soja RR. Planta Daninha, v. 29, n. 4, p. 929-937, 2011. https://doi.org/10.1590/S010083582011000400024.

Andrade, C.L.L.; Silva, A.G.; Braz, G.B.P.; Oliveira Jr., R.O.; Simon, G.A. Performance of soybeans with the application of glyphosate formulations in biostimulant association. Revista Caatinga, v. 33 , n. 2 , p. 371-383, 2020. https://doi.org/10.1590/198321252020v33n210rc.

Andrade, C.L.L.; Silva, A.G.; Melo, G.B.; Ferreira, R.V.; Moura, I.C.S.; Siqueira, G.G. Bioestimulantes derivados de Ascophyllum nodosum associados ao glyphosate nas características agronômicas da soja RR ${ }^{\circ}$. Revista Brasileira de Herbicidas, v.17, n.3, e592, 2018. https://doi.org/10.7824/rbh.v17i3.592.

Barroso, A.A.M.; Albrecht, A.J.P.; Reis, F.C.; Filho R.V. Interação entre herbicidas inibidores da ACCase e diferentes formulações de glyphosate no controle de capim-amargoso. Planta Daninha, v.32, n.3, p.619-627, 2014. https://doi.org/10.1590/S010083582014000300018

Bertolin, D.C.; Sá, M.E.; Arf, O.; Furlani Jr. E.; Colombo, A.S.; Carvalho, F.L.B.M. Aumento da produtividade de soja com a aplicação de bioestimulantes. Bragantia, v.69, n.2, p.339-347, 2010. https:// doi.org/10.1590/S0006-87052010000200011.

Bossolani, J.W.; Poloni, N.M.; Lazarini, E.; Bettiol, J.V.T.; Fischer Filho, J.; Negrisoli, M.M. Development of RR soybean in function of glyphosate doses and Bradyrhizobium inoculation. Revista Brasileira de Engenharia Agrícola e Ambiental, v.22, n.12, p.854-858, 2018. https://doi.org/10.1590/1807-1929/agriambi. v22n12p854-858.

Cesco, V.J.S.; Krenchinski, F.H.; Rodrigues, D.M.; Nardi, R.; Albrecht, A.J.P. Albrecht, L.P. 2018. Desempenho agronômico da soja Intacta RR2 submetida a doses de glifosato. Planta Daninha, v36, e018168727, 2018. https://doi.org/10.1590/s010083582018360100109.

Du Jardin, P. Plant biostimulants: definition, concept, main categories and regulation. Scientia Horticulturae, v.196, n.1, p.3-14, 2015. https://doi.org/10.1016/j.scienta.2015.09.021.

Empresa Brasileira de Pesquisa Agropecuária - Embrapa. Centro Nacional de Pesquisa Agropecuária de Solos. Sistema brasileiro de classificação de solos. Brasília: Embrapa Produção de Informação; Embrapa Solos, 2013. 154p.

Forte, C.T.; Menegat, A.D.; Galon, L.; Agazzi, L.R.; Franceschetti, M.B.; Basso, F.J.; Bagnara, M.A.M.; Chechi, L.; Perin, G.f. Effects of glyphosate and foliar fertilizers on the glyphosate resistant (GR) soybean. Australian Journal of Crop Science, v.13, n.8, p.12511257, 2019. https://doi.org/10.21475/ajcs.19.13.08.p1527.
Franco, D.A.S.; Almeida, S.D.B.; Cerdeira, A.L.; Duke, S.O.; Moraes, R.M.; Lacerda, A.L.S.; Matallo, M.B. Avaliação do uso de glyphosate em soja geneticamente modificada e sua relação com o ácido chiquímico. Planta Daninha, v.30, n.3, p.659-666, 2012. https://doi.org/10.1590/S0100-83582012000300023.

Instituto Nacional de Meteorogia - INMET. Dados meteorológicos. Município de Quatro Irmãos, RS. http://www.inmet.gov.br/ portal. 17 Feb. 2020.

Marques, M.E.R.; Simonetti, A.P.M.M.; Rosa, H.A. Aspectos produtivos do uso de bioestimulantes na cultura da soja. Acta Iguazu, v.3, n.4, p.155-163, 2014. http://e-revista.unioeste.br/ index.php/actaiguazu/article/view/12295. 18 Jan. 2020.

Melhorança Filho, A.L.; Martins, D.; Pereira, M.R.R.; Espinosa, W.R. Efeito de glyphosate sobre características produtivas em cultivares de soja transgênica e convencional. Bioscience Journal, v.26, n.3, p.322-333, 2010. http://www.seer.ufu.br/ index.php/biosciencejournal/article/viewFile/7056/4844. 18 Jan. 2020.

Melo, M.S.C.; Rocha, L.J.F.N.; Brunharo, C.A.C.G.; Nicolai, M.; Tornisiello, V.L.; Nissen, S.J.; Christoffoleti, P.J. Mecanismo de resistência do capim-amargoso ao herbicida glifosato. Planta Daninha, v37, e019185746, 2019. https://doi.org/10.1590/ s0100-83582019370100033.

Merotto Jr, A.; Wagner, J.; Meneguzzi, C. Efeitos do herbicida glifosato e da aplicação foliar de micronutrientes em soja transgênica. Bioscience Journal, v.31, n.2, p.499-508, 2015. https://doi.org/10.14393/BJ-v31n2a2015-22307.

Pinto, C.C.; Oliveira, C.O.; Américo, G.H.P.; Vazquez, G.H.; Lazarini, E. Efeito da dose e da época de aplicação do glifosato na produção e na qualidade da soja RR. Revista de Ciências Agrárias, v.39, n.2, p.310-317, 2016. https://doi.org/10.19084/RCA15076.

Pires, H.F. Bioestimulante na recuperação de fitotoxicidade causada por herbicidas aplicados em pós emergência na cultura da soja. Uberlândia: Universidade Federal de Uberlândia, 2017. 32p. Undergraduate Thesis. https://repositorio.ufu.br/ handle/123456789/20330. 07 Jan. 2020.

Povero, G.; Mejia, J.F., Di Tommaso, D.; Piaggesi, A.; Warrior, P. A systematic approach to discover and characterize natural plant biostimulants. Frontiers in Plant Science, v.7, e435, 2016. https://doi.org/10.3389/fpls.2016.00435.

Reddy, N.K.; Zablotowicz, R.M. Glyphosate-resistant soybean response to various salts of glyphosate and glyphosate accumulation in soybean nodules. Weed Science, v.51, n.4, p.496-502, 2003. https://doi.org/10.1614/00431745(2003)051[0496:GSRTVS]2.0.CO;2.

Rede Oficial de Laboratórios de Análise de Solo e de Tecido Vegetal - Rolas. Manual de calagem e adubação para os estados do Rio Grande do Sul e de Santa Catarina. Porto Alegre: Sociedade Brasileira de Ciência do Solo; Núcleo Regional Sul: Comissão de Química e Fertilidade do Solo-RS/SC, 2016. 376p.

Reis, T.C.; Nevs, A.F.; Andrade, A.P.; Santos, T.S. Efeitos de fitotoxidade na soja RR tratada com formulações e dosagens de Glifosato. Revista de Biologia e Ciências da Terra, v.10, n.1, p. 34-43, 2010. http://joaootavio.com.br/bioterra/workspace/ uploads/artigos/reis-515635ac247da.pdf. 17 Feb. 2020. 
Sharma, S.H.S.; Lyons, G.; Mcroberts, C.; Mccall, D.; Carmichael, E.; Andrews, F.; Swan, R.; McComack, R.; Mellon, R. Biostimulant activity of brown seaweed species from Strangford Lough: compositional analyses of polysaccharides and bioassay of extracts using mung bean (Vigno mungo L.) and pak choi (Brassica rapa chinensis L.). Journal of Applied Phycology, v.24, p.10811091, 2012. https://doi.org/10.1007/s10811-011-9737-5.

Sociedade Brasileira da Ciência das Plantas Daninhas - SBCPD. Procedimentos para instalação, avaliação e análise de experimentos com herbicidas. Londrina: SBCPD, 1995. 42p.
Zadinelo, R.; Chaves, M.M.; Santos, R.F.; Bassegio, D.; Werncke, I. Influência da aplicação de glifosato na produtividade da soja. Acta Iguazu, v.1, n.1, p.1-8, 2012. http://e-revista.unioeste.br/ index.php/actaiguazu/article/view/7712. 07 Jan. 2020.

Zobiole, L.H.S.; Kremer, R.J.; Oliveira Jr., R.S.; Constantin, J. Glyphosate affects photosynthesis in first and second generation of glyphosate-resistant soybeans. Plant Soil, v.336, n.1-2, p.51-265, 2010. https://doi.org/10.1007/s11104-0100474-3. 